\title{
RETRACTED
}

\section{MODEL-DRIVEN ENGINEERING FOR HIGH-PERFORMANCE COMPUTING APPLICATIONS}

David Lugato*, Jean-Michel Bruel**, Ileana Ober** and Benjamin Venelle*

${ }^{*}$ CEA-CESTA, ${ }^{* *} I R I T /$ Université de Toulouse

France

Retraction to: Lugato D, Bruel JM, Ober I, Venelle B. Model-driven Engineering for High Performance Computing Applications. In: Cakaj S, editor. Modeling Simulation and Optimization - Focus on Applications. Rijeka: InTech; 2010. pp. 19-30. DOI: 10.5772/8969

The publisher is retracting [1] due to an authorship dispute. All authors have agreed with the retraction of this chapter.

The publisher regrets any inconvenience this might have caused to the readership.

\section{References}

[1] Retraction to: Lugato D, Bruel JM, Ober I, Venelle B. Model-driven Engineering for HighPerformance Computing Applications. In: Cakaj S, editor. Modeling Simulation and Optimization

- Focus on Applications. Rijeka: InTech; 2010. pp. 19-30. DOI: 10.5772/8969 
(c) 2010 The Author(s). Licensee IntechOpen. This chapter is distributed under the terms of the Creative Commons AttributionNonCommercial-ShareAlike-3.0 License, which permits use, distribution and reproduction for non-commercial purposes, provided the original is properly cited and derivative works building on this content are distributed under the same license. 